Pontifícia Universidade católica do Rio de Janeiro

As interações em rede do ecossistema empreendedor e inovador universitário Um estudo de caso da UFRJ.

Fábio Soares da Fonseca

Trabalho de Conclusão de Curso

Centro de clênCIAs SociaIs - CCS

Departamento de Administração

Graduação em Administração de Empresas 
Fábio Soares da Fonseca

\section{As interações em rede do ecossistema empreendedor e inovador universitário Um estudo de caso da UFRJ}

Trabalho de Conclusão de Curso

Trabalho de Conclusão de Curso, apresentado ao programa de graduação em Administração da PUC-Rio como requisito parcial para a obtenção do titulo de graduação em Administração.

Orientadora: Patrícia Ítala Ferreira

Rio de Janeiro, novembro de 2009 


\section{Agradecimentos}

Aos Deuses, Deusas e Orixás pela força que me fizeram chegar até aqui. A minha família, pois sem eles nada disso teria sido possível. Aos meus amigos, pela ajuda e alegria que tanto fortaleceram a conclusão desse trabalho. E a minha orientadora Patrícia Ítala Ferreira, por toda a paciência e dedicação comigo. 


\section{Resumo}

Fonseca, Fábio Soares. As interações em rede do ecossistema empreendedor e inovador universitário - Um estudo de caso da UFRJ. Rio de Janeiro, 2019. 45 p. Trabalho de Conclusão de Curso - Departamento de Administração. Pontifícia Universidade Católica do Rio de Janeiro.

A inovação aberta costuma ser compreendida somente pela ótica da empresa, pois ela é a responsável por inovar. Porém, a universidade, através do Parque Tecnológico, Incubadora e Agência de Inovação, pode ser um ator relevante e proporcionar às empresas possibilidades de conexão frutíferas numa rede de inovação aberta e hélice tríplice. A pesquisa de campo qualitativa e a pesquisa bibliográfica buscaram verificar como funciona a rede interna da UFRJ para as conexões com o exterior. Foram identificadas diferentes níveis de relação entre universidade e empresa, barreiras e gaps com relação a comunicação interna. Apesar disso, todos os entrevistados demonstraram consciência dos benefícios do contato com as empresas.

Palavras- chave

Inovação Aberta; Redes; Hélice Tríplice.

\section{Abstract}

Fonseca, Fábio Soares. Network interactions of the entrepreneurial and innovative university ecosystem - A case study of UFRJ. Rio de Janeiro, 2019. 45p. Trabalho de Conclusão de Curso - Departamento de Administração. Pontifícia Universidade Católica do Rio de Janeiro.

Open innovation is usually only understood from the company's perspective, because it is responsible for innovating. However, the university, through the Technology Park, Incubator and Innovation Agency, can be a relevant actor and provide companies with fruitful connection possibilities in a network of open innovation and triple helix. The qualitative field research and the bibliographic research sought to verify how the UFRJ internal network works for connections with abroad. Different levels of relationship between university and company, barriers and gaps in relation to internal communication were identified. Nevertheless, all respondents were aware of the benefits of contact with companies. 
Key-words

Open innovation; Networks; Triple Helix. 


\section{Sumário}

10 tema e o problema de estudo 9

1.1. Introdução ao tema e ao problema do estudo 9

$\begin{array}{ll}\text { 1.2. Objetivo do estudo } & 10\end{array}$

1.3. Objetivos intermediários do estudo 10

1.4. Delimitação e foco do estudo 11

1.5. Justificativa e relevância do estudo 11

2 Revisão de literatura $\quad 13$

2.1. Inovação, Conhecimento e Universidades 13

2.1.1. Modos de conversão do conhecimento 14

2.1.2. A Universidade empreendedora e a transferência tecnológica 15

2.2. Inovação Aberta e Redes $\quad 16$

2.2.1. A força dos laços $\quad 17$

2.2.2. Exploration e Exploitation em redes de inovação 20

2.3. Hélice Tríplice e a Interação Universidade-Empresa 21

2.3.1. Parques Científico-Tecnológicos e Incubadoras 22

3 Métodos e procedimentos de coleta e de análise de dados do estudo 24

3.1. Etapas de coleta de dados 24

3.2. Fontes de informação selecionadas para coleta de dados no estudo 24

3.3. Procedimentos e instrumentos de coleta de dados utilizados no estudo 25

3.4. Formas de tratamento e análise dos dados coletados para o estudo 25

3.5. Limitações do Estudo $\quad 25$

4 Apresentação e análise dos resultados $\quad 27$

4.1. A Empresa $\quad 27$

4.2. Descrição e análise dos resultados 29

4.2.1. Perfil dos Respondentes 29

4.2.2. Rede distribuída e UFRJ desintegrada 30

4.2.3. Papéis institucionais e conexões internas 32

4.2.4. Interação com o Ensino 34 
4.2.5. Interface U-E 35

4.2.6. Inovação Aberta e Hélice Tríplice 38

5 Conclusões e recomendações para novos estudos 40

5.1. Sugestões e recomendações para novos estudos 41

6 Referências Bibliográficas 42

7 Apêndice 43 


\section{Lista de figuras}

Figura 1: Diagrama de redes de Baran.

Figura 2: Fonte de recursos do Parque Tecnológico.

Figura 3: Receitas do Parque Tecnológico com cessão de uso do solo.

Figura 4: Valores contratados em 2018 por modalidade de cooperação.

\section{Lista de Tabelas}

Tabela 1: Conversão dos conhecimentos.

Tabela 2: Características de redes e laços para estratégias de exploration e exploitation.

Tabela 3: Perfil dos respondentes 


\section{O tema e o problema de estudo}

Esse capítulo volta-se à apresentação do tema que se pretende desenvolver e do problema de estudo.

\subsection{Introdução ao tema e ao problema do estudo}

A nossa economia e sociedade passaram por grandes momentos e fases de transformação, desde a agricultura até a indústria, respectivamente, que protagonizaram anos que hoje passam a ser pautados pelo conhecimento, na chamada economia do conhecimento. A transformação digital atinge hoje todas as indústrias e setores, sem exceção. As novas tecnologias vieram para acelerar processos, otimizar custos e digitalizar os dados, trazendo maior eficiência operacional e eficácia no alcance dos resultados das empresas. Com a transformação digital, algumas mudanças na dinâmica das relações de trabalho, fronteiras empresariais e circulação de conhecimento estão sendo experienciadas, de forma planejada ou não (MATTOS, 2017).

Com a era do conhecimento em voga, as universidades passam a ter papel de destaque na sociedade e na economia de um país. A revolução industrial foi responsável por institucionalizar uma lógica opressora de gestão através do comando-controle, que reprimia qualquer chance de ideias inovadoras surgirem (MATTOS, 2017).

Com a revolução digital, uma nova lógica é inaugurada. Com as ideias, pessoas e conhecimento tendo maior facilidade de interação e circulação, característica presente hoje devido a revolução digital, as empresas entenderam que limitar o tema da inovação ao departamento de Pesquisa e Desenvolvimento (P\&D) era uma miopia, e que poderia perder benefícios advindos dessa abertura.

Do ponto de vista individual, as pessoas também vêm sofrendo as consequências da era da informação. Novas profissões e cargos, jornadas dupla de trabalho e novos modelos de negócio instigaram demandas dos colaboradores por novas formas de emprego e trabalho. As fronteiras tradicionais das empresas começam a ser questionadas, o propósito e as 
relações pessoais ganham prioridade com relação a motivação e felicidade (MATTOS, 2017).

Papéis inovadores e novos designs organizacionais podem ser o resultado de alguns conflitos de interesses que antes só eram vistos pelas implicações negativas (ETZKOWITZ, 2009). Ainda assim, é vaga a compreensão sobre o papel das relações sociais em configurações de inovação aberta, ou seja, sobre o processo de buscar inovação além das fronteiras da empresa. (RASS et al, 2013).

O estudo das redes sociais pode ajudar a compreender o papel de cada ator no ambiente de inovação aberta e em modelos de hélice tríplice. O novo desafio para essa economia baseada no conhecimento é fazer com que as empresas se tornem competitivas e capazes de responder às demandas de serviços e produtos inovadores, ao mesmo tempo que promovam a sinergia entre os diversos setores da sociedade e o desenvolvimento econômico em prol do bem-estar social (ZOUAIN; PLONSKI, 2006).

A inovação tem como lócus a empresa. O lócus da invenção está na universidade. A inovação aberta costuma ser compreendida pela ótica da empresa, pois ela é a responsável por inovar. Porém, a universidade pode ser um ator relevante e proporcionar às empresas possibilidades de conexão numa rede de inovação aberta. O Parque Tecnológico da UFRJ, a Incubadora da COPPE e a Agência de Inovação tornam-se veículos pelos quais a empresa pode se relacionar e inovar.

Com as fronteiras cada vez mais difusas, universidade e empresa passam a interagir em diferentes níveis dentro de redes que extrapolam essa interação. Como funciona, em termos de redes, o ecossistema de inovação e empreendedorismo da universidade, no caso, a UFRJ?

\subsection{Objetivo do estudo}

Entender como os atores do ecossistema de inovação e empreendedorismo da universidade (professores, incubadora, parque tecnológico e agência de inovação) se relacionam internamente, ou seja, entre si, e externamente, com as empresas, no contexto da inovação aberta e hélice tríplice. 


\subsection{Objetivos intermediários do estudo}

Dentre os objetivos intermediários para se alcançar o objetivo final do estudo, seguem:

- Pesquisar, por meio de pesquisa bibliográfica: Como ocorrem as interações com as empresas

- Identificar os principais laços presentes em interações de Inovação Aberta

- Verificar como é organizada a rede interna da UFRJ para que essa interação ocorra

- Entender a interferência do Governo na interação universidade empresa

- Realizar uma pesquisa de campo com atores da universidade que possuem papel relevante em relação à inovação.

\subsection{Delimitação e foco do estudo}

Para esta pesquisa, foi valorizado o uso de variáveis relacionadas às redes sociais e interpessoais, àquelas ligadas a forma como o conhecimento circula por essas redes e as implicações ideológicas no resultado prático do trabalho do dia a dia, utilizando-se a plataforma da hélice tríplice para isso.

Esta pesquisa não leva em consideração todos os conceitos e aspectos da inovação. Centra-se na ideia de que a inovação é parte de um processo coletivo e se debruça sobre as relações interpessoais para entender o potencial interno de criação de redes e de circulação do conhecimento.

A crescente relevância da universidade para a economia do conhecimento vivenciada hoje instigou a delimitação deste artigo para um recorte no contexto das universidades. O foco está no entendimento da estrutura interna, a rede interpessoal interna e externa, nas relações entre universidade (UFRJ) e empresa no contexto da Inovação Aberta. A Incubadora de empresas, o Parque Tecnológico e a Agência de Inovação serão o foco desta pesquisa. 
A pesquisa de campo foi realizada na UFRJ, nos prédios dos atores em foco, entre outubro e novembro de 2019.

\subsection{Justificativa e relevância do estudo}

Como a velocidade em inovar se tornou questão de vantagem competitiva e uma variável crítica de sucesso (ARANHA, 2009), a rapidez das inovações pode acarretar em avaliações superficiais e iniciativas questionáveis quanto à organização da universidade empreendedora e seus institutos. A Política de Inovação da UFRJ está atualmente em construção, sinalizando um amplo campo de estudo na área que introduza um conceito de formulação de métricas para a avaliação dessas políticas ao longo do tempo. Um estudo preliminar da estrutura interna da UFRJ e como essa estrutura se relaciona com o exterior, ou seja, com as empresas, se torna necessário.

Devido às fronteiras das empresas e da universidade estarem mais difusas, o entendimento de como funciona a rede de inovação interna da universidade, e de como os atores dessa rede se relacionam com o exterior, se torna relevante para delimitar os papéis de cada instituição dentro do ecossistema e otimizar o processo inovador em rede. 


\section{Revisão de literatura}

Neste capítulo são discutidos aspectos conceituais e estudos relacionados ao tema em investigação e que servirão de base para a análise realizada. São apresentados, então, conceitos de inovação e inovação aberta, redes de inovação, a força de laços pessoais e as características que envolvem as relações entre universidades e empresas.

\subsection{Inovação, Conhecimento e Universidades}

Com a globalização e o passar dos anos, a nossa sociedade passou por grandes momentos e fases de transformação até chegar ao modelo atual, baseada no conhecimento. Isso coloca a inovação como competência central das empresas do século XXI. Essas transformações impactam diretamente as empresas, que hoje em dia já entenderam que a inovação é fundamental para a sua sobrevivência. A inovação, numa definição mais prática, é o processo no qual se pensa, se cria e se distribui coisas novas, que serão consumidas (ARANHA, 2009). Ainda segundo Aranha (2009), a variável crítica de sucesso para as empresas passa a ser o tempo, a velocidade em inovar.

Freeman (1982) difere a inovação da invenção: a invenção é a ideia ou um modelo de melhoria para um processo ou produto, e a inovação é a efetivação dessa ideia ou melhoria, ou seja, quando leva-se para o mercado. (apud CALIA; MOURA, 2006).

Outras visões mais exógenas da inovação trazem percepções com relação às competências que geram inovação, quando colocadas como parte de uma atividade coletiva, através de uma rede, suas relações e ligações. (MAZZUCATO, 2014).

O conhecimento está em constante fluidez, e pode ser transformado e criado dentro das empresas, instituições de pesquisa, universidades e outros atores. Esse processo ocorre também fora dos limites e fronteiras de uma organização, encaminhando-se no nível das redes formadas por muito agentes 
diferentes, como empresas, consultores, laboratórios, usuários, institutos de pesquisa e universidades (HASEGAEWA; FURTADO, 2001).

Segundo Aranha (2009), há dois tipos de conhecimento: o explícito e o tácito. O conhecimento tácito é a habilidade física, know-how, intuições e humano e é incapaz de ser transmitido. Já o conhecimento explícito é aquele baseado em regras, formal e sistemático, que pode ser transmitido facilmente.

Polayni $(1958,1966)$ complementa que o conhecimento tácito é aquele em que se sabe mais do que se é capaz de dizer, ou seja, ele é implícito, contextual e subjetivo (apud HASEGAEWA; FURTADO, 2001). Pode ser compartilhado mais facilmente por indivíduos de uma mesma organização, pois depende de elementos culturais, ligados ao tecido cognitivo, em que as pessoas que dividem o mesmo ambiente compartilham e compreendem melhor entre si (HASEGAEWA; FURTADO, 2001).

Já o conhecimento codificado, ou explícito, é coletivizado mais facilmente porque traz como característica o fato de ser não-rival e poder ser utilizado por muitos indivíduos ao mesmo tempo (HASEGAEWA; FURTADO, 2001).

\subsubsection{Modos de conversão do conhecimento}

Um dos objetivos dos modos de conversão do conhecimento é transformar o aprendizado individual em coletivo (ARANHA, 2009). Segundo Hasegawa e Furtado (2001, p.3), "uma organização não pode criar conhecimento sozinha, então a base do processo é o conhecimento tácito dos indivíduos, que estão dentro e fora dos limites de uma mesma organização." Ainda segundo os autores, existem duas dimensões para a conversão do conhecimento: a dimensão tácito/codificado e a individual/coletivo. A tabela 1 explica esses modos de conversão.

Tabela 1: Conversão dos conhecimentos.

\begin{tabular}{|l|l|l|}
\hline \multicolumn{1}{|c|}{ Modo de conversão } & \multicolumn{1}{|c|}{ Como é feito } & \multicolumn{1}{c|}{ Exemplo/prática } \\
\hline Socialização & $\begin{array}{l}\text { Interação de } \\
\text { conhecimentos tácitos }\end{array}$ & $\begin{array}{l}\text { Local de encontro para } \\
\text { troca de ideias }\end{array}$ \\
\hline Externalização/articulação & $\begin{array}{l}\text { Transformação do } \\
\text { conhecimento tácito em } \\
\text { explícito }\end{array}$ & Escrever um projeto \\
\hline
\end{tabular}




\begin{tabular}{|l|l|l|}
\hline Internalização & $\begin{array}{l}\text { Transformação do } \\
\text { conhecimento explícito em } \\
\text { tácito }\end{array}$ & $\begin{array}{l}\text { Conclusões de um } \\
\text { relatório/Criação de um } \\
\text { novo produto }\end{array}$ \\
\hline Interação/combinação & $\begin{array}{l}\text { Combinação de } \\
\text { conhecimentos explícitos }\end{array}$ & $\begin{array}{l}\text { Geração de novos } \\
\text { conhecimentos }\end{array}$ \\
\hline
\end{tabular}

Fonte: Próprio autor (2019).

\subsubsection{A Universidade empreendedora e a transferência tecnológica}

De acordo com Chesbrough (2003), o papel da universidade no novo paradigma de inovação aberta é intensificado, e ela passa a ser o lugar de novas descobertas fundamentais para o processo de inovação ocorrer. E complementa: "And industry will need to work with universities to transfer those discoveries into innovative products, commercialized through appropriate business models." (CHESBROUGH, 2003, p.191).

Uma universidade empreendedora, segundo Etzkowitz (2009), é baseada em quatro pilares: liderança acadêmica, controle jurídico sobre os recursos acadêmicos, capacidade organizacional para a transferência tecnológica e um espírito empreendedor entre gestores, corpo docente e estudantes.

Para Aranha (2009), o desenvolvimento de novas habilidades e conhecimentos sobre como estruturar ambientes de confiança, ou seja, ambientes que permitem o compartilhamento de informações e a troca de experiências, será um dos grandes desafios imposto à universidade na formação de empreendedores. A confiança interpessoal e a reciprocidade são valores da cultura cívica que auxiliam na formação de redes de cooperação. (ARANHA, 2009).

O estímulo da transferência de tecnologia e a promoção de parcerias de pesquisadores para com as organizações é uma forma mais aberta de captação de projetos inovadores por parte da universidade (CHESBROUGH, 2003 apud DESIDÉRIO; ZILBER). Além disso, minimizar as barreiras no processo de absorção e transferência do conhecimento, pela ótica do aumento de redes de inovação envolvendo universidades e empresas é um dos requisitos para que a inovação aberta tenha resultado efetivo (DESIDÉRIO; ZILBER, 2016).

Algumas das principais barreiras identificadas na transferência tecnológica são a recente formação das equipes gestoras das políticas de inovação das universidades, a limitação de recursos para a operacionalização dessas equipes 
e divergências de objetivos em ambas as instituições (DESIDÉRIO; ZILBER, 2016).

Etzkowitz (2009, p. ), comenta que "a transferência de tecnologia tem sido vista como uma extensão da tarefa de ensino e de pesquisa acadêmicos, e, então, tem sido retida no cerne da esfera acadêmica." A transferência de tecnologia pode ser descrita como as atividades que realizam a transferência formal de invenções produzidas pelas pesquisas científicas realizadas pela universidade para o setor produtivo (STEVENS; TONEGUZZO; BOSTROM, 2005 apud CRISTOFOLETTI; SERAFIM, 2017).

Essas atividades são assumidas, de acordo com Lemos e Andreassi (2016), pelos Núcleos de Inovação Tecnológica (NITs), que são intermediadores do processo de transferência de tecnologia e financiamento desses sistemas. Os autores complementam que os NITs têm papel de fomentar as interações entre universidade e empresa, montando o fluxo de transferência, e de gerir os ativos intelectuais produzidos na universidade.

\subsection{Inovação Aberta e Redes}

Chesbrough (2006) é o criador do termo Inovação Aberta, que se opõe à inovação fechada no que diz respeito as fronteiras que produtos, processos e conhecimento se limitam. Na inovação fechada, esses ativos permanecem sob o controle e conhecimento da empresa que os gerou. O conceito de inovação aberta vem exatamente para quebrar esse paradigma das fronteiras tradicionais das empresas para que os fluxos de ideias, propriedade intelectual (PI) e indivíduos possam fluir, tanto de dentro para fora, quanto de fora para dentro. (CHESBROUGH, 2003).

Sendo assim, Chesbrough (2003) inaugura uma nova forma de pensar os laboratórios de Pesquisa e Desenvolvimento (P\&D) das empresas, que sempre foram voltados para o paradigma da inovação fechada. Essa nova lógica deve explorar o fim do monopólio do conhecimento, ou seja, a difusão do conhecimento, que pode ser comprovada pelo maior número de empresas com patentes registradas nos Estados Unidos (EUA), o maior número de empresas de fora dos EUA com patentes registradas e também pelo maior número de alunos estrangeiros que estão recebendo títulos de graduação e pós graduação em universidades americanas. (CHESBROUGH, 2003). 
O fim do monopólio do conhecimento, a crescente quantidade de patentes e o efeito real deste número nos resultados em inovação é questionada por Mazzucato (2014). Segundo a autora, é importante explicar porque essa relação não é necessariamente de causa e consequência. Dentre outros fatores, a ampliação dos tipos de invenções que podem ser patenteados e o fato de o capital de risco usar as patentes como sinal para investimento, ou seja, a valorização do número de patentes por empresas que querem obter financiamento, são alguns sinais que fizeram com que a quantidade de patentes crescesse bastante, sem que houvesse um retorno efetivo para o aumento de inovação (MAZZUCATO, 2014).

A inovação aberta pressupõe algumas ações internas que dão continuidade a uma função crítica dos departamentos internos de P\&D. É preciso reestruturar a arquitetura desse departamento para que ele consiga, através de uma hierarquia de conexões, trazer novas tecnologias úteis para todo o sistema de P\&D. (CHESBROUGH, 2003).

Como apresentado anteriormente, a inovação aberta pressupõe o rompimento das fronteiras tradicionais da empresa para que ideias, propriedade intelectual e indivíduos fluam livremente (CHESBROUGH, 2003). Essa abordagem é conhecida como aberta porque as fronteiras do funil de desenvolvimento de produtos são permeáveis (DITTRICH; DUYSTERS, 2007).

Dittrich e Duysters (2007) argumentam que uma abordagem de inovação aberta é o resultado complexo de uma rede de relações com outras organizações, que terão como objetivo servir a diferentes propósitos em diferentes momentos. Ainda segundo os autores, as redes de inovação são particularmente importantes em indústrias nas quais a tecnologia muda de forma muito rápida e onde os ciclos de vida dos produtos são mais curtos.

\subsubsection{A força dos laços}

Como as redes de inovação são criadas com um propósito claro e definido, elas vão mudar radicalmente a estrutura interna de grandes empresas, as relações industriais de grandes empresas e potencialmente as estruturas das indústrias. (DITTRICH; DUYSTERS, 2007).

A figura 1 representa o diagrama de Baran (apud MATTOS, 2017) e ajuda a entender e a diferenciar os três tipos de rede mais frequentes. A primeira diz respeito ao modelo centralizado, no qual, do coração da rede, um nó, se conecta 
a todos os outros nós (MATTOS, 2017). O autor cita como exemplos deste tipo de rede as estruturas totalitárias e redes nas quais a informação que sai de um interlocutor chega da mesma forma para todos os outros nós. Outro ponto relevante desse tipo de rede é que dois nós periféricos só conseguiriam interagir se, necessariamente, passassem pelo interlocutor central (MATTOS, 2017).

O segundo tipo de rede apresentado no diagrama de Baran é conhecido como rede descentralizada, onde há dois tipos de ligações: os nós periféricos se conectam a subestações ou diretamente ao centro (MATTOS, 2017). Ainda segundo o autor, esse tipo de rede tem um fluxo de informação, teoricamente, mais ágil em comparação com a rede centralizada, mas na prática a gestão hierarquizada torna essas interações de periferia pouco relevantes.

O último modelo de rede do diagrama de Baran (apud MATTOS, 2017) é o modelo distribuído. Nesse tipo de rede, há um maior nível de horizontalização, a interação entre os nós é muito mais ágil e vários exemplos desse modelo podem ser vistos pós-revolução digital (MATTOS, 2017).

A rede distribuída, segundo Mattos (2017), é a mais sustentável, pois a perda de qualquer nó não compromete a estrutura da rede. $O$ autor complementa que essas redes são mais flexíveis, e absorvem organicamente novas conexões. Possuem estruturas abertas para novos entrantes (MATTOS, 2017).

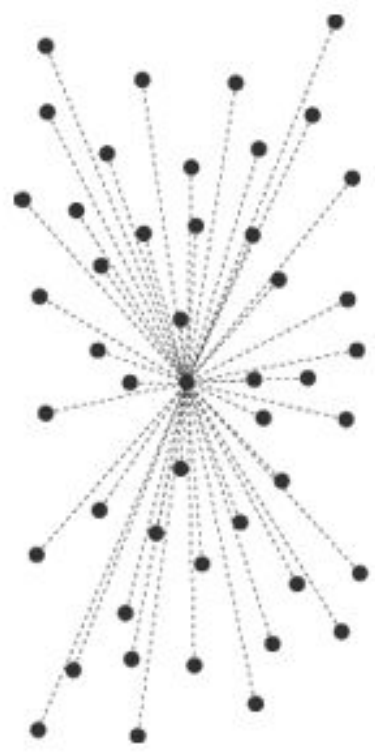

CENTRALIZED

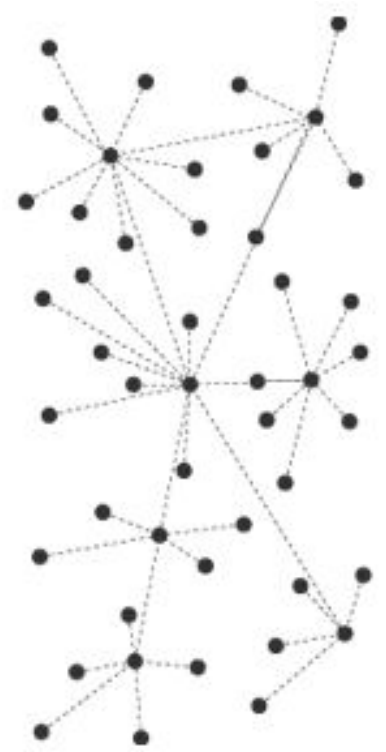

DECENTRALIZED

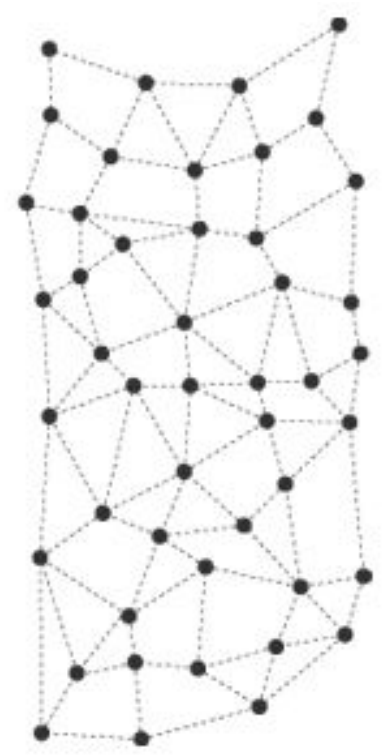

DISTRIBUTED 
Figura 1: Diagrama de redes de Baran.

Fonte: Mattos, 2017.

A ampliação da rede de contatos é uma das formas das empresas conseguirem conquistar um melhor desempenho; empresas sem interações renegam a possibilidade de novidade e enfrentam alto risco de morte (LEMOS; ANDREASSI, 2016). O estudo das redes e a análise dos processos em redes interpessoais fornece uma frutífera ponte entre micro e macro níveis, ou seja, é por essas redes que as interações em pequenas escalas se tornam traduzidas em padrões de grande escala (GRANOVETTER, 1973).

A partir do número de conexões pode-se ter a compreensão do papel de cada ator na rede, conceito denominado centralidade (LEMOS; ANDREASSI, 2016). Os autores complementam que, em relação ao número de conexões realizadas, enquanto o ator periférico alcança poucos outros atores na rede, o ator central é mais ativo. "Estudos empíricos já demonstraram as externalidades positivas da centralidade" (LEMOS; ANDREASSI, 2016, p.5).

Para Gomes et al (2003), centralidade é definido apenas de forma indireta e que não apresenta uma definição clara. (apud TOMAÉL; MARTELETO, 2006). Ainda segundo os autores, "um indivíduo é central em uma rede quando pode comunicar-se diretamente com muitos outros, ou está próximo de muitos outros, ou, ainda, quando há muitos atores que o utilizam como intermediários em suas comunicações." (apud TOMAÉL; MARTELETO, 2006).

Segundo Burt (1992), "falhas nas estruturas das redes que impedem a comunicação entre os atores são conhecidas como structural holes ou vazios estruturais. Significa o relacionamento de não redundância entre dois ou mais atores numa rede social" (apud LEMOS; ANDREASSI, 2016, p.1). Para Hoang e Antoncic (2003), ainda conforme citado por Lemos e Andreassi (2016, p. 2), vazios estruturais "são lacunas na estrutura da rede que podem ser preenchidas por um ator intermediário, que se beneficia ao manter contato com outros atores desconectados pelo eventual acesso a uma diversidade de recursos". Mcevily e Zaheer (1999) completam que a existência de vazios estruturais é o que define o potencial de inovação de uma rede (apud LEMOS; ANDREASSI, 2016).

A perspectiva relacional extrapola a quantidade de conexões e traz para o debate a importância do conteúdo acessado por essas redes e a descrição de como os recursos são alcançados (LEMOS; ANDREASSI, 2016). Além do número de conexões, essas redes são constituídas por laços pessoais que 
podem ser caracterizados como fracos ou fortes. A força de um laço é a combinação (provavelmente linear) da quantidade de tempo, intensidade emocional, intimidade (confidencialidade mútua), e os serviços recíprocos que caracterizam o laço (GRANOVETTER, 1973).

Segundo Granovetter (1973), cada laço é independente um do outro, ainda embora que o todo seja correlacionado.

Hansen (1999) considera que laços fracos são úteis na busca de conhecimentos relevantes, mas impedem a transferência de conhecimentos complexos, para os quais são necessários laços fortes (apud RASS et al, 2013). Da mesma forma, Ahuja (2000) argumenta que o valor dos vínculos diretos, indiretos e buracos estruturais nas redes entre firmas depende do contexto e dos objetivos dos membros da rede (apud RASS et al, 2013).

Conceitos de outros autores podem agregar na reflexão sobre a força dos laços presentes nas redes interpessoais. De acordo com Kale, Singh e Perlmutter (2000), critérios como nível de verdade, reciprocidade, confiança e legitimidade são características que podem definir se um laço é forte ou fraco (apud LEMOS; ANDREASSI, 2016). Já Krackhardt (1992) cita o longo prazo das interações, que permite a redução de conflitos nas relações de troca e a reprodução de coesão local como critérios para a força dos laços (apud LEMOS; ANDREASSI, 2016). Outro ponto relevante é que as interações que são caracterizadas como laços fracos terão um comprometimento menor do que aquelas que possuem laços mais fortes (DITTRICH; DUYSTERS, 2007).

\subsubsection{Exploration e Exploitation em redes de inovação}

Hansen, Podolny, e Pfeffer (2001), Afuah (2000), e Rowley, Behrens e Krackhardt (2000) encontraram fortes evidências de que o valor de laços fracos e fortes depende do tipo de aprendizado que se deseja obter e do ambiente externo (apud DITTRICH; DUYSTERS, 2007). Ou seja, as redes de inovação são caracterizadas por estratégias distintas de acordo com seus objetivos. Essas estratégias de redes entre organizações oferecem flexibilidade, velocidade, inovação e a possibilidade de pequenos ajustes durante o processo, de acordo com mudanças de mercado e novas oportunidades estratégicas (DITTRICH; DUYSTERS, 2007).

Segundo March (1991), a estratégia de exploration de novas ideias e possibilidades está associada com a busca, experimentação, a maior atração por 
riscos e inovação (apud DITTRICH; DUYSTERS, 2007). Quando a empresa opta por adotar a estratégia de exploration as empresas evitam entrar em parcerias inflexíveis porque querem ter a oportunidade de abandonar a parceria a qualquer momento, já que não sabem se a tecnologia vai se tornar útil para suas atividades (DUYSTERS; DE MAN, 2003 apud DITTRICH; DUYSTERS, 2007).

Granovetter (1973) comenta que, frequentemente, essas novas ideias e possibilidades surgem de relações com parceiros de setores e linhas de negócio distintos, pois essas empresas vão possibilitar o acesso a diferentes bases de conhecimento. Além disso, para a estratégia de exploration, as alianças e parcerias estabelecidas serão frequentemente com parceiros novos, àqueles que antes nunca haviam se relacionado (GRANOVETTER, 1973). Sob essas condições de rápidas alterações tecnológicas onde existe a necessidade de aprendizado exploratório, a importância dos laços fracos é maior (Afuah, 2000 apud DITTRICH; DUYSTERS, 2007).

Já estratégias de exploitation objetivam o fortalecimento e ampliação de conhecimentos básicos de produtos e tecnologias já estabelecidas (DITTRICH; DUYSTERS, 2007). De acordo com Krackhardt (1992), conforme citado por Dittrich e Duysters (2007), maximizar o número de laços fortes, nesse caso, iria enriquecer o acesso a base de conhecimentos de produtos e tecnologias já estabelecidas, tendo como indicador o número de conexões com parceiros dos mesmos setores e verticais de atuação.

Uma intensa relação entre os parceiros é um pré requisito para a estratégia de exploitation, ou seja, uma intensa troca de conhecimento, que pode ser atingido através de laços fortes, pois só eles têm a intensidade para isso. (DITTRICH; DUYSTERS, 2007). Consequentemente, ainda segundo os autores, estratégias de exploration levam a um menor comprometimento de parcerias de P\&D em novas capacidades tecnológicas, pois o foco está em aprender novas ideias de novos parceiros. Estratégias de exploitation, por outro lado, vão levar a altos níveis de comprometimento nas parcerias referentes as competências tecnológicas existentes (DITTRICH; DUYSTERS, 2007). A tabela 2 consolida as diferenças e características de cada estratégia de redes para a inovação.

Tabela 2: Características de redes e laços para estratégias de exploration e exploitation.

\begin{tabular}{|l|l|l|}
\hline & \multicolumn{1}{|c|}{ Exploration } & \multicolumn{1}{|c|}{ Exploitation } \\
\hline Capacidade dos parceiros & Parceiros com & Parceiros com \\
\hline
\end{tabular}




\begin{tabular}{|l|l|l|}
\hline & capacidades diferentes & capacidades semelhantes \\
\hline Tipos de parceiro & Parceiro novo & $\begin{array}{l}\text { Parceiro conhecido ou } \\
\text { familiar }\end{array}$ \\
\hline Tipos de parceria & Sem equity & Com equity \\
\hline $\begin{array}{l}\text { Tipos de laços mais } \\
\text { efetivos }\end{array}$ & Laços fracos & Laços fortes \\
\hline
\end{tabular}

Fonte: Dittrich e Duysters (2007, p. 514.)

Laços fortes, que, por outro lado, caracterizam-se por uma íntima, recorrente e confiante relação, ajudam em casos de uso da estratégia de exploitation (KRACKHARDT, 1992 apud DITTRICH; DUYSTERS, 2007).

Rowley, Behrens e Krackhardt (2000) nos mostram que laços fortes são mais efetivos para propósitos de exploitation, enquanto para estratégias de exploration os laços fracos têm mais valor (apud DITTRICH; DUYSTERS, 2007).

\subsection{Hélice Tríplice e a Interação Universidade-Empresa}

"É observado que o contexto da hélice tríplice se coaduna com a formação de redes, estruturado em sistemas de inovação, com um papel bem distinto entre os atores." (DESIDÉRIO; ZILBER, 2016).

Como foi visto na teoria de Chesbrough (2003) sobre inovação aberta, empresas e universidades vão precisar trabalhar cada vez mais juntas para que as novas descobertas de cientistas e pesquisadores da academia se transformem em inovações, agregando valor assim para a sociedade como um todo.

A interação U-E pode ser analisada pela ótica da plataforma da hélice tríplice, conceituada por Etzkowitz (2009). Nela, o autor diz que Universidades, Empresas e Governo, eventualmente, assumem o papel do outro, sem que suas missões originais e papéis primários sejam deturpados. E complementa: "As universidades empreendedoras têm um papel chave na hélice tríplice, que ocorre por meio da transferência de tecnologia, da incubação de novas empresas e da condução de esforços de renovação regionais." (ETZKOWITZ, 2009 , p. 19). Aqui pode-se compreender uma abordagem semelhante à da Inovação Aberta, com foco na universidade. 
Apesar disso, Mazzucato (2014) levanta a questão do modelo de inovação aberta estar se tornando disfuncional, devido ao fato de as grandes empresas estarem cada vez mais dependentes das pequenas e do setor público. Para a autora, há vários indícios de que as grandes empresas investem mais em ganhos no curto prazo do que nos investimentos de longo prazo, e isto pode causar o problema da socialização dos riscos e privatização dos benefícios.

A plataforma da Hélice Tríplice vem também como uma alternativa aos modelos estatista e laissez-faire (ETZKOWITZ, 2009). O modelo produzido por Etzkowitz (2009) traz contribuições sobre o porquê das três esferas manterem relações de independência, mostra onde essas interações ocorrem e explica o motivo desse modelo poder ser formado com graduações entre independência e interdependência, conflito e confluência de interesse.

A abordagem da Hélice Tríplice na América Latina vem sendo bastante questionada porque as interações entre universidade, empresa e governo não seguem o modelo ideal descrito pela teoria, devido ao padrão de produção periférico (CRISTOFOLETTI; SERAFIM, 2017).

\subsubsection{Parques Científico-Tecnológicos e Incubadoras}

Os parques tecnológicos são "a forma mais completa de cooperação entre uma universidade e/ou instituto de pesquisa com o meio empresarial" (ZOUAIN; PLONSKI, 2006, p. 13). Nos parques tecnológicos e arranjos produtivos, ou seja, nos habitats de inovação, formas de arranjos interorganizacionais, dirigidas pela cooperação, também podem ser identificadas (ARANHA, 2009).

Para Zouain e Plonski (2006), além da economia do conhecimento, outro fenômeno que vem se desenvolvendo de forma acelerada é a globalização dos mercados. Como consequência disso, a disseminação do conhecimento como base para a competitividade empresarial, regional e nacional precisa ser estimulada através de políticas e mecanismos estruturados (ZOUAIN; PLONSKI, 2006).

\footnotetext{
Nesse contexto, tornam-se ainda mais importantes sistemas e modelos de cooperação que estabeleçam relações profícuas e duradouras entre as universidades e institutos de pesquisa e o segmento empresarial. Essas relações contribuem expressivamente para a renovação dessas organizações e as capacitam a melhor lidar com as novas demandas, cada vez mais complexas. (ZOUAIN; PLONSKI, 2006, p. 12)
} 
Segundo Zouain e Plonski (2016), os parques científicos e tecnológicos representam esse modelo e são reconhecidos por órgãos governamentais como instrumentos importantes de políticas públicas e desenvolvimento regional, além de serem apreciados e valorizados pelas empresas que a eles se associam.

Segundo a Associação Nacional de Entidades Promotoras de Empreendimentos Inovadores (ANPROTEC), "os parques tecnológicos constituem um complexo produtivo industrial e de serviços de base científico-tecnológica. Planejados, têm caráter formal, concentrado e cooperativo, agregando empresas cuja produção se baseia em P\&D. Assim, os parques atuam como promotores da cultura da inovação, da competitividade e da capacitação empresarial, fundamentados na transferência de conhecimento e tecnologia, com o objetivo de incrementar a produção de riqueza de uma determinada região."

Com efeito, os parques científicos e tecnológicos apresentam algumas características: têm base física, onde empresas inovadoras e intensivas em conhecimento podem se localizar; integram políticas públicas com o objetivo de incrementar inovação e competitividade nas regiões que se localizam e empresas; impulsionam a criação de empresas inovadoras; promovem integração das empresas com instituições de ensino e pesquisa; ajudam a difundir uma nova cultura empreendedora e inovadora na cidade; e possuem uma entidade gestora para o trato com as empresas, ações de obtenção de financiamentos entre outras atribuições (ZOUAIN; PLONSKI, 2006).

"A Incubadora de empresa tem o objetivo de oferecer suporte a empreendedores para que eles possam desenvolver ideias inovadoras e transformá-las em empreendimentos de sucesso. Para isso, oferece infraestrutura e suporte gerencial, orientando os empreendedores quanto a gestão do negócio e sua competitividade" (ANPROTEC). 


\section{Métodos e procedimentos de coleta e de análise de dados do estudo}

Este capítulo pretende informar sobre as diversas decisões a respeito da forma como este estudo foi realizado.

\subsection{Etapas de coleta de dados}

Vergara (2009) comenta em sua obra sobre a importância de correlacionar os objetivos aos meios para atingi-los. Sendo assim, quanto aos fins, esta pesquisa se caracteriza como descritiva, pois expõe as características da população, alguns agentes da comunidade acadêmica da UFRJ, a respeito do fenômeno da interface entre universidade e empresa, utilizando-se de alguns conceitos das redes sociais.

Quanto aos meios, esta pesquisa pode ser considerada bibliográfica, pois usou como base materiais publicados em livros, sites e teses; de campo, pois o pesquisador esteve presente fisicamente no local onde ocorre o fenômeno estudado, ou seja, a universidade, incubadora, agência de inovação e parque tecnológico; e, por último, é também um estudo de caso, pois está circunscrita na comunidade acadêmica da UFRJ, seus centros e institutos, e tem caráter de detalhamento (VERGARA, 2009).

\subsection{Fontes de informação selecionadas para coleta de dados no estudo}

O universo desta pesquisa pode ser compreendido pelos centros, institutos, e organizações da UFRJ que, de uma forma ou de outra, apresentam certo nível de interface com a iniciativa privada, e que também possuam relações com temas como empreendedorismo e inovação. 
A seleção dos sujeitos foi feita com base em critérios de acessibilidade e tipicidade. Ou seja, elementos representativos da população-alvo e de fácil acesso para o pesquisador foram selecionados para responder às entrevistas (VERGARA, 2009).

De uma forma geral, os respondentes da entrevista foram gestores das instituições que participam do ecossistema de empreendedorismo e inovação da UFRJ, como o Parque Tecnológico, a Incubadora e a Agência de Inovação, além de professores de uma disciplina integrada de empreendedorismo.

\subsection{Procedimentos e instrumentos de coleta de dados utilizados no estudo}

Ainda com base em Vergara (2009), a coleta dos dados foi dividida em duas etapas. Primeiramente, uma etapa bibliográfica, no qual foram consultados materiais e conceitos importantes para a investigação empírica a posteriori, dentre eles o relatório de sustentabilidade do Parque Tecnológico de 2018, que enriqueceu essa pesquisa com números relevantes sobre a cooperação U-E no âmbito do Parque Tecnológico.

Em um segundo momento, o instrumento utilizado foi a entrevista por pautas, pois pretendia-se aprofundar com mais detalhes o relacionamento que os atores do ecossistema de inovação e empreendedorismo da UFRJ estavam submetidos, tanto no ambiente interno quanto no externo. A entrevista por pautas foi elaborada objetivando-se o entendimento do papel de cada ator nessa rede de inovação da universidade, os modos de relacionamento que esses atores possuem entre si e o tipo de cooperação que cada ator pode construir com alguma empresa. Foram quatro modelos de entrevistas que seguem em apêndice.

\subsection{Formas de tratamento e análise dos dados coletados para o estudo}

Todas as entrevistas foram gravadas e, posteriormente, transcritas, a fim de se obter um maior detalhamento das informações que se teve acesso. Nesse processo, o pesquisador se preocupou em agrupar visões semelhantes a respeito do processo interno do funcionamento das redes da universidade, e contrapor pontos divergentes dos entrevistados entre si e entre a bibliografia 
consultada. Os dados são tratados aqui de forma qualitativa, e, por isso são apresentados de forma mais estruturada, sendo analisados posteriormente (VERGARA, 2009).

\subsection{Limitações do Estudo}

Nem todos os tipos de interações com empresas foram consideradas para esta pesquisa. Por exemplo, não foram consultados materiais quantitativos a respeito da Agência de Inovação da UFRJ, como progressão do número de patentes e valores em reais transacionados. Outro ponto que não foi levado em consideração foi a atuação dos laboratórios nessa interface de conexão U-E.

Além disso, a coleta de dados foi feita com uma pessoa de cada instituição (Parque Tecnológico, Incubadora e Agência de Inovação) e dois professores, o que pode trazer vieses e percepções pessoais para a pesquisa que não traduzem a realidade total, prejudicando o estudo. Apesar da seleção dos sujeitos não ser representativa do ponto de vista quantitativo, a relevância de cada entrevistado no contexto da inovação aberta e da interação universidade empresa possibilitou insights relevantes sobre o tema abordado.

A realização de entrevistas, por ter no pesquisador uma figura chave, pode também conter vieses e interpretações pessoais com impactos nos entrevistados e nas interpretações realizadas. Outro limitador do estudo foi o tempo disponível dos entrevistados para a realização das entrevistas.

Mesmo com as limitações indicadas, acredita-se que o estudo atingiu seus objetivos, contribuindo para uma melhor compreensão do relacionamento universidade-empresa no contexto da inovação aberta. 


\section{Apresentação e análise dos resultados}

Este capítulo, organizado em 2 seções, apresenta e discute os principais resultados alcançados, analisa e discute suas implicações e produz sugestões sobre o estudo previamente selecionado.

\subsection{A Empresa}

Ao estudar a interação universidade-empresa na UFRJ, trazer alguns números sobre o parque e refletir o impacto deles em planejamentos, papéis e funções de cada ator na rede de inovação é importante. "Fortalecer a capacidade de inovação do ecossistema para a criação de riqueza e bem-estar da sociedade em um ambiente de conexões de iniciativas empreendedoras e geração de conhecimento" (PARQUE TECNOLÓGICO DA UFRJ, 2018, p. 20), é a missão do Parque Tecnológico da UFRJ.

A figura 2 apresenta os números sobre cada fonte de recurso do parque tecnológico que são quatro: cessão de uso dos prédios compartilhados, taxa de serviço de terrenos, taxas de serviços dos prédios compartilhados e fomento. Vale destacar que a principal fonte de recurso do Parque em 2018 foi a Finep, uma agência pública de fomento à ciência, tecnologia e inovação, representando $40 \%$ do total dos recursos captados pelo Parque no ano passado.

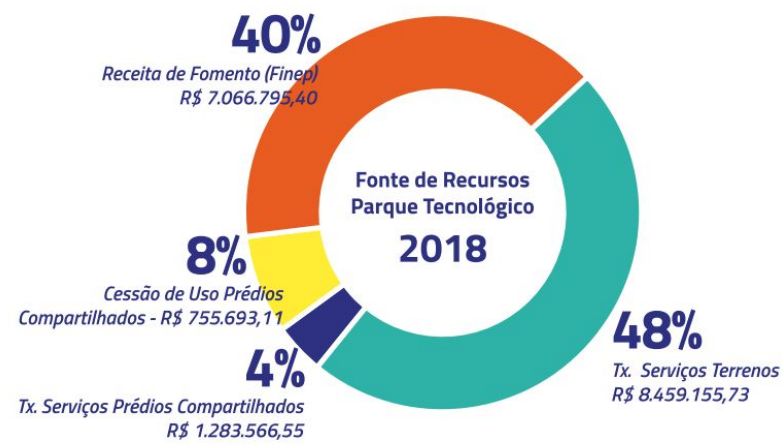


Figura 2: Fonte de recursos do Parque Tecnológico.

Fonte: Parque Tecnológico da UFRJ (2018, p. 63).

Outro número relevante que pode somar a análise da pesquisa é a progressão dos recursos repassados integralmente para a UFRJ do ano de 2009 a 2018, especificamente os recursos financeiros gerados com a cessão de terrenos. A figura 3 retrata esses números.

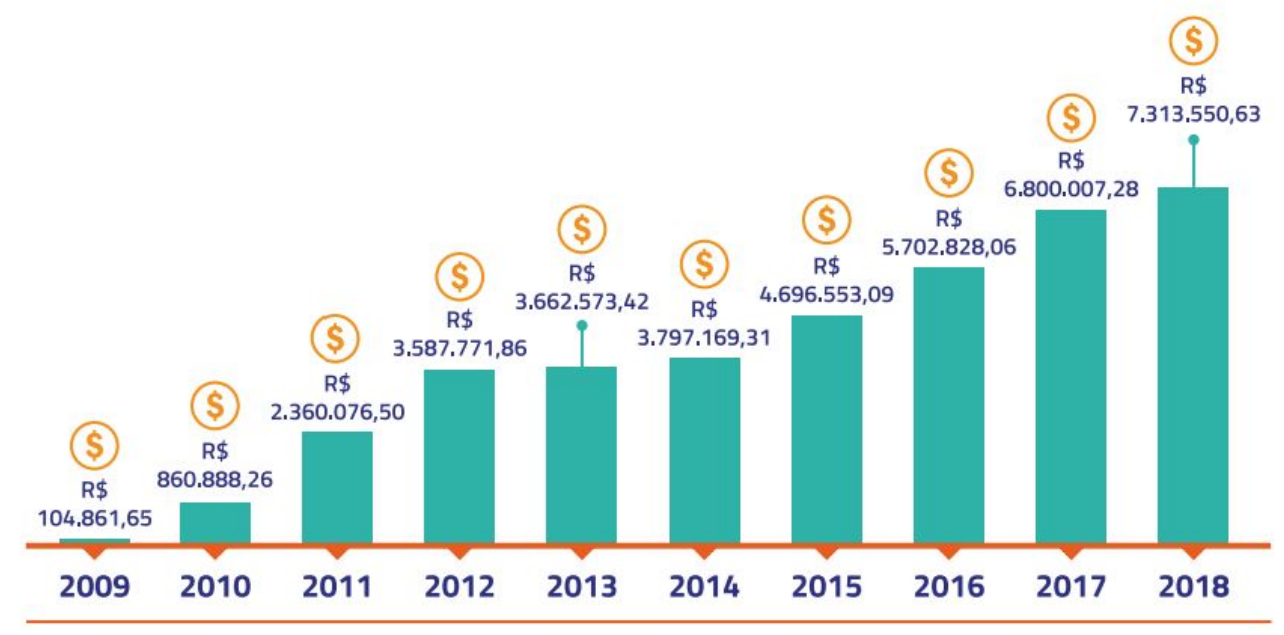

Figura 3: Receitas do Parque Tecnológico com cessão de uso do solo.

Fonte: Parque Tecnológico da UFRJ (2018, p. 64).

Outra prerrogativa do parque tecnológico é a dinamização de economias regionais e nacionais, agregando-lhes conteúdos de conhecimento e inovação tecnológica. Sendo assim, algumas iniciativas que o parque promove contribuem para o desenvolvimento dos alunos da UFRJ através de oportunidades de emprego, contato com desafios reais de grandes empresas e levando para o dia a dia da universidade o tema da inovação.

Algumas dessas iniciativas são a oferta de estágios aos estudantes, o investimento social em projetos de ações afirmativas e estratégias de integração empresas-universidade.

Tratando-se de valores contratados por grandes empresas em projetos de cooperação com a universidade, um montante de $\mathrm{R} \$ 8.704 .892,71$ foi acordado para que 98 projetos saíssem do papel. Desse total, $R \$ 4.824 .802,09$ foram direcionados a Pesquisa e Desenvolvimento.

A figura 4 apresenta os valores contratados por modalidades de cooperação em 2018: 


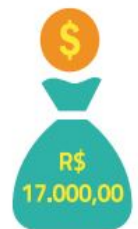

Doação

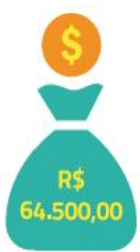

Evento

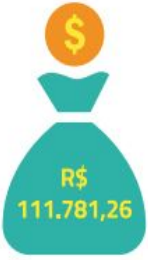

Incubadora

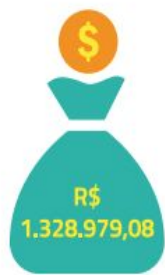

Serviços

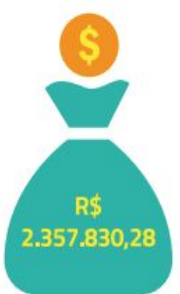

Ensino

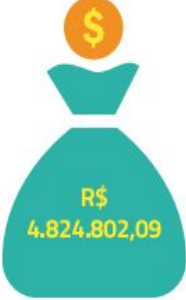

P\&D

Figura 4: Valores contratados em 2018 por modalidade de cooperação.

Fonte: Parque Tecnológico da UFRJ (2018, p. 90).

Em 2018, 55\% da cooperação realizada foi direcionado para pesquisa e desenvolvimento, contra $97 \%$ em 2017 . Já o ensino recebeu $27 \%$ dos valores contratados em 2018, e em 2017 esse percentual foi de apenas 0,34\%.

Esses números traduzem a atuação do Parque com relação aos modelos de inovação aberta que oferece para as empresas que interagem com a UFRJ.

\subsection{Descrição e análise dos resultados}

\subsubsection{Perfil dos Respondentes}

A tabela 3 destaca o perfil dos cinco respondentes da pesquisa de campo.

Tabela 3: Perfil dos respondentes

\begin{tabular}{|c|l|l|l|l|}
\hline Respondente & \multicolumn{1}{|c|}{ Instituição } & \multicolumn{1}{|c|}{ Cargo } & \multicolumn{1}{c|}{$\begin{array}{c}\text { Tempo no } \\
\text { cargo }\end{array}$} & \multicolumn{1}{c|}{ Formação } \\
\hline Gestor 1 & $\begin{array}{l}\text { Incubadora } \\
\text { COPPE/UFRJ }\end{array}$ & Gerente & 5 anos & $\begin{array}{l}\text { Graduação em } \\
\text { Comunicação PUC-Rio, } \\
\text { Mestrado em } \\
\text { Administração } \\
\text { COPPEAD/UFRJ }\end{array}$ \\
\hline Gestor 2 & $\begin{array}{l}\text { Parque } \\
\text { Tecnológico da } \\
\text { UFRJ }\end{array}$ & $\begin{array}{l}\text { Gerente de } \\
\text { articulações }\end{array}$ & 3 anos & $\begin{array}{l}\text { Graduação em } \\
\text { Engenharia de Produção } \\
\text { UFRJ, Mestrado em }\end{array}$ \\
\hline Gestor 3 & $\begin{array}{l}\text { Agência de } \\
\text { Inovação da } \\
\text { UFRJ }\end{array}$ & Coordenador & 12 anos & $\begin{array}{l}\text { Graduação em Economia, } \\
\text { PUC/Campinas, Mestrado } \\
\text { em Engenharia de } \\
\text { Produção COPPE/UFRJ }\end{array}$ \\
\hline Professor 1 & $\begin{array}{l}\text { Departamento } \\
\text { de engenharia } \\
\text { de produção da }\end{array}$ & Professor & 4 anos & $\begin{array}{l}\text { Graduação, Mestrado e } \\
\text { Doutorado em Engenharia } \\
\text { de Produção UFRJ }\end{array}$ \\
\hline
\end{tabular}




\begin{tabular}{|c|l|l|l|l|}
\hline & UFRJ & & & \\
\hline Professor 2 & $\begin{array}{l}\text { Departamento } \\
\text { de Medicina da } \\
\text { UFRJ }\end{array}$ & Professora & 17 anos & $\begin{array}{l}\text { Graduação em } \\
\text { Medicina, Mestrado em } \\
\text { Ciências Biológicas, } \\
\text { Doutorado em Ciências } \\
\text { Biológicas e Doutorado } \\
\text { em Políticas Públicas, } \\
\text { Estratégia e } \\
\text { Desenvolvimento UFRJ }\end{array}$ \\
\hline
\end{tabular}

Fonte: Próprio autor (2019).

\subsubsection{Rede distribuída e UFRJ desintegrada}

Com relação à rede da UFRJ, algumas respostas dos entrevistados indicam que se trata de um modelo distribuído, e que, conforme assinalado por Baran (apud MATTOS, 2016), traz suas externalidades positivas no que diz respeito à flexibilidade e sustentabilidade que possuem. "São vários centros, cada centro tem as suas unidades e elas têm uma grande versatilidade, cada um pode dar a disciplina que quiser e bem entender" afirma o Professor 2. O Professor 1 complementa: "O lado positivo da rede da universidade ser distribuída é que é muito difícil de você ser marcado. Como é distribuído, você sempre tem uma porta ou uma janela pela qual dá para você passar."

Apesar de Mattos (2016) não levantar aspectos negativos das redes distribuídas, os entrevistados ponderam: "A UFRJ é muito abrangente, funciona muito desintegrada em seus díspares centros. Por isso, o NIT (Núcleo de Inovação Tecnológica) da UFRJ tem dificuldades de atuar." apontou o Professor 2. "O lado negativo é que (esse modelo distribuído) é pouco eficiente, a gente tem muita iniciativa de tudo na UFRJ, várias disciplinas de empreendedorismo, muitos laboratórios com impressão $3 \mathrm{~d}$ e por aí vai. Acaba sendo um certo desperdício de recursos. Esses pares não conversam entre si, é uma zona, tem muita repetição. Mas o trabalho que gente faz é se aproximar de algumas pessoas, não todas, porque não somos bobos nem permissivos", acrescentou o Professor 1.

O Parque Tecnológico apresenta sua visão sobre esse assunto . "A gente apresenta os pares, que às vezes estão dispersos. Em todo evento de conexão que eu faço aqui escuto a seguinte frase: 'não sabia que eu tinha uma pessoa 
trabalhando numa coisa que tem muita sinergia com meu trabalho.' A gente tem esse papel de conectar, e aqui numa dimensão de conexão entre pares (interna). Por mais estranho que possa parecer, a gente ainda carece de mídias para fazer essa conexão.", disse o Gestor 2. Essas respostas também dialogam com os vazios estruturais mencionados por Burt (1992) (apud LEMOS; ANDREASSI, 2016). Ou seja, o potencial de inovação da universidade, de acordo com Mcevily e Zaheer (1999), apesar dela não ter essa responsabilidade, é muito grande (apud LEMOS; ANDREASSI, 2016).

As externalidades positivas, como consequência da centralidade da rede, conforme Lemos e Andreassi (2016) pontuaram, podem ser identificadas na fala do Gestor 2. "A universidade tem uma enorme oportunidade. Cada um desses centros que a gente vê, que tem centenas de pessoas especializadas em determinada coisa. A empresa jamais conseguiria ter um profissional para todo problema que aparecer no dia. Aonde a gente tem a maior probabilidade de encontrar isso? A universidade. E uma como a UFRJ, gigante, 60 mil alunos, milhares de professores... A probabilidade ajuda a gente a encontrar uma pessoa que entenda de branqueamento de corais, por exemplo."

Mais especificamente, ainda de acordo com o Gestor 2, o Parque Tecnológico apresenta uma maior centralidade, se comparado com as outras instituições pesquisadas, como a Incubadora e a Agência de Inovação. "Tem uma hora que têm que resolver os problemas reais que a indústria, a sociedade, e o mercado estão imprimindo. E o Parque tem muito dessa perspectiva, de ser esse interlocutor. É muito mais fácil a indústria participar de um workshop organizado por mim (pelo Parque) do que de repente de um outro organizado por um laboratório. Além de termos essa possibilidade de fazer a interlocução, temos a possibilidade de ser mais neutro. Quando to fazendo eventos, estou apresentando o mais amplo possível que a universidade pode ser, e não só atendendo a um interesse específico de um grupo. para mim o gol é marcado quando eu consigo fazer uma apresentação panorâmica da universidade. É uma função que poderia ser executada por outros membros, mas o Parque ocupa essa posição muito bem. Acho que isso tem muito valor." disse o Gestor 2. Essa fala confirma a teoria de Zouain e Plonski (2006, p.13), de que "os parques tecnológicos são a forma mais completa de cooperação entre uma universidade e/ou instituto de pesquisa com o meio empresarial". 
Apesar disso, a oferta de capturar valor pela ótica do aumento de redes de inovação envolvendo universidades e empresas, como mostram Desidério e Zilber (2016), pode ser identificada também pelos outros atores do ecossistema de inovação e empreendedorismo da universidade. "E outra questão em que ajudamos muito e eu acho que é um de nosso grandes valores são a conexão e relacionamento. Porque esse cara ainda não é ninguém no mercado, uma grande empresa dificilmente vai contratar ele porque nunca ouviu falar e não sabe se é uma empresa que vai fechar rapidamente, por exemplo. Sendo uma (startup) de dentro da incubadora da COPPE, tem uma chancela e um reconhecimento. Então a gente consegue trazer grandes empresas para se aproximarem dessas startups, e essa aproximação pode originar um projeto piloto ou ainda uma experimentação", afirma o Gestor 1.

Além dessa fala, outras corroboram com a teoria de Desidério e Zilber (2016) já comentada acima. São elas: "No que a gente está interessado para uma empresa vir para cá? A capacidade dessa empresa de interagir com a universidade. Lembra da nossa missão? Conectar universidade com a empresa, então a gente olha para esse encaixe, que a universidade pode ter com aquela empresa." afirma o Gestor 2. Já o Gestor 1 diz: "Apesar do nome ser incubadora da COPPE, ela não é só da COPPE e não incuba negócios que só saem da engenharia. As únicas exigências são que os negócios precisam ser de base tecnológica e precisam interagir com o ecossistema da UFRJ. A partir do momento que você vem para cá você tem que interagir com esse ambiente. Então você tem que ter alguma parceria com algum laboratório que tenha sinergia com o seu negócio, ou então com alguma linha de pesquisa de algum professor, ou com uma outra startup que está na incubadora, ou ainda com uma grande empresa do Parque."

\subsubsection{Papéis institucionais e conexões internas}

Entender como Agência de Inovação, Incubadora e Parque Tecnológico interagem é um dos objetivos intermediários dessa pesquisa, pois esta compreensão contribuirá para contextualizar e embasar as reflexões a respeito da interface U-E. Por isso, esta seção é dedicada às interações internas entre os atores da UFRJ e seus respectivos papéis.

Para começar, alguns dados históricos merecem inaugurar essa seção. O Parque Tecnológico e a Incubadora da COPPE possuem uma característica 
congênita. Ela pode ser ilustrada pela fala do Gestor 1: "Com o parque temos uma parceria muito estreita, quase que um cordão umbilical. A mesma pessoa que criou a incubadora, alguns anos depois, criou também o Parque Tecnológico. Tem essa característica de nascença e talvez por conta disso, as duas instituições sempre foram muito aliadas. Mas apesar dessa proximidade tão forte, institucionalmente somo filhos de mães diferentes, porque o Parque está ligado à reitoria e a incubadora está ligada à COPPE. É uma relação institucional diferente." Essa fala do Gestor 1 faz menção à força dos laços usando o critério do prazo que a interação ocorre. Krackhardt (1992) cita o longo prazo das interações, que permite a redução de conflitos nas relações de troca, e a reprodução de coesão local, como critérios para a força dos laços (apud LEMOS; ANDREASSI, 2016). Ou seja, pode-se dizer que a interação Incubadora - Parque Tecnológico é caracterizada como forte, trazendo comprometimento para a relação (DITTRICH; DUYSTERS, 2007) e facilitando a transferência de conhecimentos complexos. (Hansen, 1999 apud RASS et al, 2013)

Outro ponto crucial para a compreensão sobre o funcionamento da rede interna da UFRJ, no que concerne aos atores envolvidos com inovação e empreendedorismo, são as falas do Professor 1 e do Gestor 3 que trazem observações a respeito das propriedades e características das interações entre os pares. Conforme sustentado por Granovetter (1973), estudar esses processos em redes interpessoais pode trazer uma útil e importante ponte entre os níveis micro e macro, e assim, um maior entendimento de padrões de grande escala que são traduções de interações em pequenas escalas. Algumas dessas falas são: "Eu acho que a relação que existe aqui é pessoal. Eu gosto do (Gestor 2), acho que ele é muito competente. Mas é uma relação pessoal." conforme citado pelo Professor 1 e "As coisas aqui são muito pessoais. Têm pessoas que são mais abertas a esse tipo de interação e outras não. Eu lamento que não tenha acontecido mais (interação com o Parque Tecnológico). Inovação e Parque tem tudo a ver, então acho que poderíamos ter tido uma atuação em conjunto mais constante e efetiva." disse o Gestor 3.

Essa pessoalização dos elos institucionais entre os atores da UFRJ vai ao encontro da teoria citada por Granovetter (1973) e Rass et al (2013). O comprometimento (DITTRICH; DUYSTERS, 2007) e a transferência de conhecimentos complexos (Hansen, 1999 apud RASS et al, 2013) são identificados em relações caracterizadas com elos fortes. Pode-se inferir aqui 
que esses benefícios, dentro da rede da UFRJ, são atingidos através de interações pessoais e históricas que as instituições possuem entre si. Como Granovetter (1973) sinaliza, a força de um laço é a combinação (provavelmente linear) da quantidade de tempo, intensidade emocional, intimidade (confidencialidade mútua), e os serviços recíprocos que caracterizam o laço.

O Gestor 3 pontuou outra característica da interação com o Parque Tecnológico relevante para esta análise: "A agência de Inovação lida com PI. Teve um evento promovido pelo Parque Tecnológico sobre PI e a Agência só foi convidada para assistir. Por que não sentamos (Agência) junto com o Parque na organização do evento? Eu te garanto que de PI a Agência entende mais do que o Parque."

Já a interação Incubadora - Agência de Inovação parece ser mais estreita. O Gestor 1 alega que, com a Agência de Inovação possui um "relacionamento de parceria. A Agência está dentro da área da incubadora. Eles são nossos parceiros porque ajudam muito a gente, principalmente no eixo tecnologia. As empresas já chegam com esse tema super maduro. Em geral não precisamos ajudar eles com isso, mas o que eles não têm as vezes é parte de patente, registro de marca, PI. Isso a gente apoia eles através da Agência de Inovação, fazendo essa ponte.", termina.

Uma outra forma de interação entre os pares dentro da UFRJ pode ser analisada pela constituição dos conselhos diretores e tomadores de decisão das instituições. "O planejamento estratégico é feito pelo conselho diretor, que tem a presença de professores de todos os centros. As empresas também são convidadas a participar. O planejamento é feito muito pelo time do Parque, e também com contribuições da academia, mas na figura dos membros do nosso conselho que representam a universidade." disse o Gestor 2. O Gestor 3 complementa: "É o conselho da incubadora que escolhe as empresas que vão ser incubadas aqui. IEN, CETEM, esses órgãos participam do conselho... a reitoria, a COPPE. E tem alguns atores de fora também, como FAPERJ, Finep.”

\subsubsection{Interação com o Ensino}

Ambos os professores ouvidos nesta pesquisa externalizam seus pontos de vista com relação à graduação e sobre a turma integrada de empreendedorismo. Por isso, os comentários das falas que seguem traduzem a interação das instituições pesquisadas com relação ao ensino no nível da 
graduação. "No ensino não tem muita interação com o Parque, tem mais com laboratórios de pesquisa. Porque tem lá uma obrigatoriedade das empresas que são residentes do parque de interagir com a UFRJ. Na verdade tem algumas iniciativas isoladas, por exemplo uma empresa do Parque quer ministrar alguns cursos para nossas graduações. Ta bom, se ele tiver interesse, a gente pensa como fazer isso. Mas é isolado, não é uma coisa estruturada pelo Parque." disse o Professor 2. Já o Professor 1 comenta: "eu me relaciono bem com a incubadora e com o Parque. Com a Agência eu sempre tive uma relação mais incidental. Porque eu acho que a Agência trabalha mais com patente. Ali tem um escopo mais de patente, e eu não patenteio as coisas né? Meus alunos não patenteiam também. Então a gente nunca trabalhou junto. O que eu fiz com a Agência foi ter convidado uma das gestoras para dar uma palestra para gente numa dessas disciplinas. A aula de propriedade intelectual foi dada por ela nesse dia."

Esta seção vai abordar, também, conceitos ligados ao ensino de empreendedorismo, especificamente sobre a disciplina integrada de empreendedorismo cujos professores foram entrevistados. "São várias disciplinas que a gente abre no mesmo horário. Se eu ofereço empreendedorismo para farmácia, você pode puxar ela como livre escolha. Mas os alunos têm uma afinidade muito grande com as disciplinas de seu próprio curso. Então a gente optou por não ter um código único, cada professor abre a sua. E a gente abre todas as disciplinas no mesmo dia, mesmo horário e mesmo local e enfia todo mundo numa mesma sala de aula. Começamos isso de forma irregular, sem avisar a ninguém, e agora a reitoria está ciente de que estamos fazendo isso, e isso se tornou parte do ecossistema de inovação da UFRJ." comentou o Professor 2. O resultado dessa estratégia de divulgação da disciplina pode ser visualizado na seguinte fala do mesmo professor: "A gente já chegou num pico de alunos que vieram de 19 cursos diferentes, e baixou para 12 cursos depois dos trancamentos. Porque a ideia é a seguinte, se a gente coloca 5 caras da produção para trabalhar junto não sai nada muito interessante, mas se gente coloca um da produção com um da farmácia, o cara da farmácia tem um problema, e o cara da produção vai de alguma forma tentar resolver aquele problema. Por isso a questão da multidisciplinaridade." "Na verdade não é uma disciplina comum, com prova no meio e final como os alunos esperam. É uma disciplina que os alunos vão construindo uma possível startup ao longo do 
semestre. Passam o semestre inteiro fazendo validação do problema e do segmento, o que normalmente é negligenciado quando se pensa em startup.", complementa.

Essa estratégia se coaduna com os conceitos de Hasegaewa e Furtado (2001) sobre conversão do conhecimento. Pode-se dizer que colocar todos os alunos, de diversos cursos, com backgrounds diferentes de conhecimentos tácito e explícito, para trabalharem juntos, estimula a conversão e a troca desses conhecimentos, em todos os seus níveis. Um local de encontro para troca de ideia, escrever um projeto, criar um produto e a geração de novos conhecimentos são as iniciativas que os professores fomentam nos alunos com esse tipo de disciplina, e que são apontados por Hasegaewa e Furtado (2001) como formas de conversão, do nível tácito para o explícito e individual para o coletivo.

\subsubsection{Interface U-E}

A interação universidade-empresa foi um dos temas que nortearam a realização dessa pesquisa. Por essa razão, considerações sobre essa temática aparecem em vários momentos nas respostas dos entrevistados. Para começar, vale destacar a seguinte fala do Professor 1: "Existem vários tipos de interação, e elas são diferentes, não há um único modo de interação entre universidade e empresa. Essas interações deveriam ser pautadas por valores diferentes, já que elas são diferentes." Portanto, a análise desta seção será dividida por instituição pesquisada.

Em relação ao Parque Tecnológico, a Gestora 2 comenta: "A gente tem dois fluxos. O principal, mais frequente, é o fluxo que vem puxado pela empresa. Então a empresa que tem um desafio tecnológico, uma oportunidade, identifica um gap e nos procura para que e a gente busque na universidade quais são os pontos de conexão que ela deve fazer para encontrar a solução daquele problema. Meu time entra em cena, e a gente vai buscar os especialistas e armar esse encontro, entre empresa e especialistas. $O$ encontro pode variar muito no formato, a depender do número de especialistas identificados e também do quão amplo for o desafio que a empresa coloca. Um conjunto de profesores se apresenta para aquela demanda. Em geral, para coisas mais específicas, a agilidade do processo é muito maior.. Em compensação, quando você começa mais amplo, você encontra vários caminhos. Não tem melhor nem 
pior, depende da situação. Outro fluxo é quando a universidade apresenta algo a empresa, ou seja, algumas vezes esse fluxo vem puxado pela academia, o que representa um fluxo mais autônomo, de acordo com cada professor."

Com relação aos objetos contratuais e legais com relação ao Parque Tecnológico e empresa, a Gestora 2 complementa: "Depois que fazemos esse encontro e a conversa vai se desdobrando, chega uma hora que vai surgir uma proposta. Uma proposta comercial para uma cooperação tecnológica, por exemplo. Sendo aceita, ela se transforma num objeto contratualizado, que pode ser um convênio, um contrato... Vai depender do nível de envolvimento da universidade e empresa. É entendido junto com a empresa qual o formato que veste melhor essa relação."

Para compreender a interação Incubadora - empresa, as falas da Gestora 1 trazem alguns pontos relevantes: "A gente tem um movimento ativo e um passivo. Muitas vezes as grandes empresas procuram a gente, sem entender muito o motivo, mas querem estar próximos. Nós vemos o que podemos fazer juntos. Que tipo de empresa, quais startups faz sentido apresentar. Ou ainda fazemos hackathons e levamos desafios das grandes empresas para as startups. E tem a parte ativa. Nós buscamos grandes empresas que a gente acha que pode ser interessante, e marcamos um pitch day, que acontece uma vez por mês mais ou menos. A grande empresa fala um pouco sobre ela e as startups se apresentam para essa empresa. Desse pitch day pode sair uma parceria ou prova de conceito, por exemplo." Ela completa: "Eu acho que existe o interesse das duas partes nessa conexão. Da grande empresa estar mais próximo do ambiente acadêmico, das tecnologias que são desenvolvidas aqui dentro, de alunos e professores. E também tem o interesse da academia e das empresas incubadas nessa aproximação, para poder viabilizar o negócio. Fechar uma parceria, conseguir um cliente, testar uma validação. Acho que é uma relação muito sadia e que as duas partes têm ganhos."

Diferentemente das duas instituições citadas acima, uma outra situação se coloca para a Agência de Inovação. Pode-se identificar isso na fala do Gestor 3: "Ninguém vai bater na porta da Agência perguntando se tem patente". Essa característica da interação entre Agência de Inovação e as empresas apontam para um único fluxo, o fluxo ativo por parte da Agência. Ele continua: "A Agência teve poucos casos de sucesso, e foram temporários, não duraram muito. Hoje tem um portfolio de mais ou menos 300 patentes e uma das coisas que 
precisamos fazer é abrir mão delas, se não foram comercializadas ainda. Existe um comitê que faz isso e que precisa ser reativado. A Reitoria anterior não ativou esse comitê, que é um comitê de assessoramento para trabalhar junto da Agência e determinar quais pedidos de patentes manter e quais abrir mão. Licenciamento traz muito recurso para a instituição, mas infelizmente, hoje na UFRJ, não temos patentes licenciadas."

Como exposto por Lemos e Andreassi (2016), o NIT da UFRJ, ou seja, a Agência de Inovação, tem o papel de fomentar as interações entre universidade e empresa, montando o fluxo de transferência, e de gerir os ativos intelectuais produzidos na universidade. Uma barreira nesse processo, conforme descrito por Desidério e Zilber (2016), que pode ser identificada também na atuação da Agência de Inovação da UFRJ, é a limitação de recursos para a manutenção da equipe.

Essa barreira também pode ser visualizada nas seguintes falas: "A gente não consegue entregar tudo o que a gente gostaria de entregar, porque a equipe é minúscula", disse o Gestor 1. "Você precisa ter volume. Tem que procurar 30, 40 empresas para, de repente, uma fechar um acordo. Mas nós não tínhamos equipe o suficiente para isso." completa o Gestor 3.

Outra barreira trazida por Desidério e Zilber (2016) e também presente nas interações da UFRJ com empresas é a divergência de objetivos em ambas as instituições, sendo possível visualizar na seguinte fala do Professor 1: "Muitas vezes a empresa só quer contribuir com aquilo que funciona para ela, aquilo que vai deixar ela bem na foto. Isso tem acontecido com muitas empresas, senão com quase todas que vêm aqui se relacionar. Já teve empresa que colocou no relatório que envia pros acionistas que é parceira da UFRJ em disciplina de empreendedorismo mas não ajuda em nenhum custo operacional da disciplina, por exemplo. Então é necessário que a gente repense esse modelo de cooperação, pois ele não está nos permitindo, efetivamente, atender as necessidades que a disciplina tem para fazer o trabalho crescer."

Ao ser perguntado se isso acontecia em interações de outros níveis, o Professor 1 disse: "Empresa - Parque já é diferente porque o Parque Tecnológico pressupõe uma relação business com as empresas, então a partir do momento que não tem dúvidas sobre custos, ou seja, você tem que pagar para estar no Parque, isso a priori já evita esses espertalhões." 


\subsubsection{Inovação Aberta e Hélice Tríplice}

É possível analisar as falas de alguns dos entrevistados com conceitos de inovação aberta trazidas por Chesbrough (2003). Segundo o autor, as fronteiras tradicionais das empresas estão sendo eliminadas para que o fluxo de ideias, PI e indivíduos possam fluir livremente, e adiciona que os laboratórios de P\&D das empresas precisam ser repensados para essa nova lógica. A Gestora 2 confirma: "Até os anos 80 a discussão era de que a empresa fazia a inovação fechada, com portas fechadas, nos seus centros de pesquisa. A partir de então percebeu-se que é uma miopia, que você consegue fazer muito melhor se você abre um pouco esse jogo. E ao abrir o jogo a empresa pode fazer isso com vários jogadores, o cliente, o fornecedor, o concorrente, e a universidade. Então a universidade é um dos atores claramente identificados como parceiro em quem a empresa pode se apoiar para fazer a inovação. Quando olhamos os números do relatório de sustentabilidade do Parque, conseguimos visualizar a materialização da inovação aberta que a gente faz. A maior parte daquele recurso foi para $P \& D$, ou seja, a maior parte dos recursos foi direcionada para uma ação que mira a inovação." Pode-se perceber, considerando a fala exposta, que o Parque Tecnológico promove a Inovação Aberta em diversos níveis para a empresa.

Como Mazzucato (2014) assinalou, o modelo de inovação aberta pode estar se tornando disfuncional, pois as grandes empresas estão cada vez mais preocupadas com ganhos no curto prazo do que nos investimentos de longo prazo, além de estarem mais dependentes das pequenas empresas e do setor público.

A plataforma da Hélice Tríplice, conceituada por Etzkowitz (2009) se sobrepõe em alguns momentos as redes de Inovação Aberta e adiciona o Governo como um terceiro ator nesse modelo. As interferências do Governo nessa interação podem ser identificadas pelas seguintes falas: "A lei da inovação vem de muito tempo atrás, e vem sendo modificada. Em 2004 começou obrigando toda instituição, seja federal ou estadual, a ter um NIT. A Agência de Inovação da UFRJ é o nome fantasia para o nosso NIT. Dentre essas modificações, está o aumento no número de atribuições para cada NIT. Eram 6 atribuições, e a partir de 3 anos atrás passaram para 10. O que se torna altamente complexo, você teria poucas instituições no Brasil capaz de atender 
aquilo tudo." do Gestor 3; "Foi feito um Marco Legal de Ciência e Tecnologia, no ano passado. A partir desse Marco é que a universidade está desenvolvendo sua política de inovação. Esse Marco vai afirmar que é papel do estado de inovar, desenvolver tecnologia." do Gestor 2.

Sobre a política de inovação, o Gestor 2 complementa: "A política está em gestação nesse momento. Vários professores e partes estão participando dessa elaboração. E a política vai ter a missão de fazer essa costura, e é costura mesmo. São 3 entidades que já tem a sua maturidade, e que nenhuma é subordinada a outra, mas se a gente costurar nosso trabalho a gente consegue fazer melhor, ir mais longe."

O Professor 1 traz um ponto importante sobre o modelo da Hélice Tríplice, que vai ao encontro de Etzkowitz (2009) quando este diz que, eventualmente, as instituições deste modelo assumem o papel um do outro. "Às vezes a UFRJ tem a sua função de ensino executada por outras instituições, até privadas, isso realmente acontece. Vez ou outra a UFRJ assume o papel do Estado.. Mas o Estado mexe em dissonância com relação à universidade. O Estado Federal e Estadual. Ele não entende muito bem o que é a universidade"

Com relação aos pontos negativos que percebe nesse modelo, hoje, ele acrescenta: "A política de investimento do Estado do Rio é péssima, se comparado com São Paulo. O Rio é muito atrasado no ponto de vista da decisão de para quem vai a grana. Porque eu acho que não é verdade que o Rio não tem grana, a FAPERJ (Fundação de Amparo à Pesquisa do Estado do Rio de Janeiro) dá dinheiro. Mas é uma lógica que vai sempre pro mesmo buraco, são sempre os mesmos que ganham o dinheiro. Então hoje se você quer falar de hélice tríplice, a hélice está meio quebrada, principalmente do ponto de vista do Estado. A relação está se desgastando em parte por causa da universidade em si e em partes pela empresa também. Então eu acho que a coisa não está muito boa pelo ponto de vista da hélice tríplice para crescimento do Estado do Rio, em particular."

A Professora 2 questiona os modelos de avaliação de certas variáveis implementadas pelo Estado: "A CAPES vai começar a contabilizar startup na avaliação da pós graduação, e isso é grave. Porque isso vai começar a virar moeda. Que nem patente virou moeda. Pessoas saíram atrás de patente porque o CNPQ tava botando pontos no lattes para quem tinha patente. Agora a CAPES 
vai começar a pontuar as pós que tiverem startups saindo dali. Isso vai ser um problema." apontou a professora. 


\section{Conclusões e recomendações para novos estudos}

Este capítulo resume as principais contribuições produzidas ao tema em estudo.

O objetivo do estudo era entender, com base nos conceitos de redes, como a UFRJ se organiza internamente para interagir com as empresas, no contexto da Inovação Aberta e Hélice Tríplice. Para que se pudesse atingir esse objetivo, foi relevante compreender como ocorrem as interações com as empresas, o papel de cada ator no ecossistema de empreendedorismo e inovação da universidade, a interferência de terceiros, como o Governo por exemplo, e qual a percepção da comunidade acadêmica sobre essa interação. Pode-se dizer que o objetivo foi atingido, pois informações relevantes sobre a rede interna da universidade e sobre a interação dos atores da UFRJ com empresas foram levantadas.

A rede interna da UFRJ, no que concerne aos atores envolvidos com inovação e empreendedorismo, apresenta buracos relacionais. Alguns atores poderiam traçar um relacionamento produtivo e vantajoso para as partes se houvesse maior interação e aproximação, pois suas atuações são complementares, e isso aumentaria o potencial de criação de valor para a comunidade acadêmica.

Por outro lado, os entrevistados possuem consciência dos benefícios que o contato com o mundo exterior traz à universidade. A rede externa à UFRJ é, em todos os sentidos, estimulada a interagir com os alunos, professores e pesquisadores, sendo esse um dos pré-requisitos para as empresas se instalarem nos espaços da universidade, seja no Parque Tecnológico ou Incubadora.

Com relação a interface universidade - empresa, a UFRJ apresenta alguns pontos de contato, que precisam ser identificados de acordo com os objetivos e interesses de cada ator desta interação. Pode-se dizer que as interações com o Parque Tecnológico prevalecem no contexto da Inovação Aberta, enquanto as 
interações com a Agência de Inovação estão inseridas num contexto onde a Hélice Tríplice dita as regras, pois o Governo se coloca como um terceiro ator que atua de forma contundente nessas interações.

As relações Parque Tecnológico-empresa e Agência de Inovação-empresa podem ser descritas como uma relação na qual a estratégia de exploitation, por parte da empresa, predomina. Quando a empresa está na fase de exploration, a interação com ensino e incubadora prevalece. Isso porque as empresas, nesses níveis de interação, possuem maior flexibilidade para adaptar as suas práticas de cooperação.

\subsection{Sugestões e recomendações para novos estudos}

Esta seção sugere futuros estudos que possam, eventualmente, dar prosseguimento ao estudo aqui relatado.

Como o foco desse estudo foi entender a visão da universidade e de suas instituições a respeito da interação U-E, uma sugestão para novos estudos seria a compreensão da visão das empresas sobre a interação com a UFRJ e quais seus objetivos nessa interação.

Além disso, informações de alunos, da graduação e pós, também podem agregar bastante para o tema pesquisado.

Seria relevante ainda buscar compreender a inovação aberta em outras instituições de ensino, tanto públicas como privadas, a fim de identificar similaridades e diferenças entre as práticas que possam ser adotadas.

A pesquisa em questão teve um viés qualitativo e de escopo limitado em termos de participantes, logo, seria relevante considerar a realização de um estudo também quantitativo que abrangesse uma maior quantidade de pessoas envolvidas com inovação. 


\section{Referências Bibliográficas}

AMBIENTES DE INOVAÇÃO. Anprotec. Disponível em <http://anprotec.org.br/site/sobre/incubadoras-e-parques/> Acesso em: 19 de nov. de 2019.

ARANHA, J. A. Interfaces. São Paulo: Saraiva, 2009.

CALIA, R. C.; MOURA, G. L. Redes de Inovação para o Desenvolvimento de um Novo Software de Programação da Produção. XIXX Simpósio de Gestão da Inovação Tecnológica, 2006.

CHESBROUGH, H. W.; Open Innovation: The new imperative for creating and profiting from technology. Boston: Harvard Business School Publishing Corporation, 2003.

CRISTOFOLETTI, E. C.; SERAFIM, M. P . A relação universidade-empresa sob diferentes abordagens: da universidade empreendedora ao capitalismo acadêmico. Revista Educação, v. 40, n. 1, p. 73-82, 2017.

DESIDÉRIO, P. H. M.; ZILBER, M. A. A inovação aberta na perspectiva da hélice tríplice: observações da relação universidade-empresa na transferência tecnológica. Revista GEINTEC, v. 6, n. 2, p. 3209-3225, 2016.

DITTRICH, K.; DUYSTERS, G. Networking as a Means to Strategy Change:

ETZKOWITZ, H. Hélice tríplice. Porto Alegre: EDIPUCRS, 2009.

GRANOVETTER, M. S.; The Strength of Weak Ties. American Journal of Sociology, v. 78, n. 6, p. 1360-1380, 1973.

LEMOS, A. Q.; ANDREASSI, T. A Influência da Centralidade e dos Laços Relacionais em Redes de Inovação Tecnológica na Geração De Vantagem Competitiva Empresarial. XIXX Simpósio de Gestão da Inovação Tecnológica, 2016.

MATTOS, T.; Vai lá e Faz. Rio Grande do Sul: Belas Letras, 2017. 
MAZZUCATO, M; O Estado empreendedor. São Paulo: Portfolio-Penguin, 2014

Mirian HASEGAWA, M.; FURTADO, A. T. Em direção a um modelo de criação e circulação do conhecimento em redes de inovação. XXV Encontro da ANPAD, 2001.

Parque Tecnológico da UFRJ. Relatório de Sustentabilidade do Parque Tecnológico da UFRJ 2018. Rio de Janeiro, 2018. Dlsponível em: $<$ https://www.parque.ufri.br/wp-content/uploads/2019/08/Relatorio de_Sustentabi lidade_PTec_2018_web_full.pdf>. Acesso em: 19 de nov. de 2019.

RASS, M.; DUMBACH, M.; DANZINGER, F.; BULLINGER, A. C.; MOESLEIN, K. M. Open Innovation And Firm Performance. Creativity and Innovation Management, v. 22, n. 2, p. 177-194, 2013.

The Case of Open Innovation in Mobile Telephony. J PROD INNOV MANAG, v. 24, p.510-521, 2007.

TOMAÉL, M. I.; MARTELETO, R. M. Redes sociais: posições dos atores no fluxo da informação. Encontros Bibli: revista eletrônica de biblioteconomia e ciência da informação. v.11, n.1, p. 75-91, 2006.

VERGARA, S. A.; Projetos e relatórios de pesquisa em administração. Sâo Paulo: Atlas S.A., 1998.

ZOUAIN, D. M.; PLONSKI, G. A. Parques tecnológicos. Brasília: ANPROTEC: SEBRAE, 2006. 


\section{$7 \quad$ Apêndices}

\section{Roteiro entrevista geral:}

Nome, formação, cargo, experiência com empreendedorismo e inovação

Como é o seu relacionamento com outros atores do ecossistema de empreendedorismo e inovação da UFRJ?

Como a sua instituição se relaciona com as outras?

\section{Roteiro entrevista agência de inovação}

Como você enxerga a confiança da academia com relação ao benefício que as patentes trazem?

Como o conhecimento de uma patente pode agregar valor para uma empresa?

Quais os usos que as empresas que interagem com patentes da UFRJ mais dão a ela?

De que outras formas as empresas podem se apropriar do conhecimento gerado na UFRJ?

De que forma a agência de inovação promove a cooperação U-E, alem das patentes? Promove a Inovação Aberta?

Como você enxerga a rede que a agência da ufrj faz parte? quem são esses atores, com quem vocês se relacionam? é uma rede densa ou dispersa?

Qual a diferença da atuação da agencia para o parque? Como vocês trabalham juntos? Como essa relação na sua opiniao poderia ser melhorada?

Como você classifica os elos que ligam a agência da ufrj com esses atores? São ligações fortes ou fracas? 
Como você enxerga as vantagens que esses laços fracos e fortes trazem? Os dois são importantes?

\section{Roteiro entrevista parque tecnológico}

Como se dá o processo de fechar um projeto de cooperação grande empresa/startup ou grande empresa/universidade?

Qual a importância dessa relação U-E para a universidade?

Quais as partes contratuais e legais envolvidas nesse processo?

Qual o papel dos professores nesse processo de cooperação universidade empresa?

Como funciona o critério de seleção dos projetos de cooperação?

Como funciona o critério de seleção para as empresas que vão estar no parque/fazer projetos de cooperação com a universidade e/ou startups?

Como o parque e as empresas que fecham projetos de cooperação fazem a prestação de contas/transparência das informações desses projetos para a comunidade?

Qual o nível de importância que a comunidade acadêmica tem nas decisões dos projetos com as empresas?

Já houve algum problema com alguma cooperação entre U-E?

Como vocês traçaram as metas do planejamento estratégico de vocês? A comunidade acadêmica (professores e alunos) foram ouvidos, tiveram alguma voz nisso? Quem participa dessas determinações?

De 2017 para 2018, os temas que receberam investimento em PeD diminuíram de 51 para 28. Porque isso aconteceu? Quais as possíveis consequências para a UFRJ? Quem define esses temas são as empresas? 
Você acha que faltam estudos sobre o papel da Universidade na Inovação Aberta?

\section{Roteiro entrevista incubadora}

Vocês utilizam alguma metodologia para a gestão da incubadora? Tipo o CERNE, da ANPROTEC?

Um dos valores da incubadora, segundo o relatório de sustentabilidade do parque em 2018, é a autocrítica. Como a incubadora exerce esse valor no dia a dia dela?

Vocês, como incubadora da COPPE, exercem a inovação aberta através de quais iniciativas?

Como a incubadora promove a conexão entre empresas, alunos e startups? Como vocês se veem utilizando o conceito de redes para fazer essas conexões?

\section{Roteiro entrevista professores}

Dedicação integral?

Você já participou de algum projeto de cooperação universidade empresa?

Qual o papel dos professores nesse processo de cooperação universidade empresa?

Você classifica a UFRJ como uma universidade empreendedora?

Como enxerga o nível de maturidade e atratividade dos alunos com relação ao tema do empreendedorismo e inovação?

Os alunos questionam assuntos relacionados ao limite dessa interação U-E? 
Como você enxerga que a Universidade empreendedora deve ser formulada? Como universidade pode gerar renda com o conhecimento que produz?

Qual o seu relacionamento com o parque tecnologico? E com a incubadora? E com a agência de inovação? Com as empresas? Você se relaciona com algum outro ator nesse ecossistema?

Quais os maiores ganhos que você pode perceber na cooperação ou no trabalho colaborativo? E as maiores dificuldades?

Inovação e conhecimento, por sua vez, são vantagens competitivas. Como a Universidade pode usar isso para garantir a sua autonomia universitária e trazer retorno para os estudantes e a comunidade?

O que você acha da abordagem da Hélice Triplice?

Como está sendo essa disciplina de empreendedorismo? É a primeira vez que ela acontece? Vocês dão conceitos de inovação?

Como a partir do estudo das redes o conhecimento pode circular e gerar a inovação? Como outros institutos da UFRJ podem colaborar com o ensino aos estudantes?

Você acha que os alunos deveriam estar mais envolvidos nessas interações U-E? 